\title{
UMA SINTESE HISTÓRICO JURÍDICA DA SEGURANÇA ALIMENTAR E NUTRICIONAL E DO IMPACTO AMBIENTAL DOS AGROTÓXICOS
}

\author{
A LEGAL HISTORICAL SYNTHESIS OF FOOD AND NUTRITIONAL SAFETY AND THE \\ ENVIRONMENTAL IMPACT OF PESTICIDIS
}

Vânia Márcia Damasceno Nogueira

Defensora Pública Federal de Categoria Especial Mestre em Direito pela Universidade de Itaúna/MG Membro do Grupo de Trabalho Segurança Alimentar e Nutricional da DPU

vania.nogueira@dpu.def.br

\section{RESUMO}

O presente artigo tem o objetivo pincelar estatutos conceituais, históricos e legislativos sobre a Segurança Alimentar e Nutricional no âmbito do Direito, debatendo o modelo atual agropecuário dos países em desenvolvimento, em especial Brasil e Chile, apontando os impactos ambientais nocivos do uso indiscriminado de agrotóxicos e discutir o Pacote do Veneno (PL no 6.299/2002) e o seu opositor legislativo PNaRA (PL no 6.670/16).

Palavras-chave: Segurança Alimentar e Nutricional. Agronegócio. Agrotóxico. 


\begin{abstract}
The purpose of this article is to outline conceptual, historical and legislative statutes on Food and Nutrition Security within the scope of Law, debating the current agricultural model of developing countries, especially Brazil and Chile, pointing out the harmful environmental impacts of the indiscriminate use of pesticidis and discuss the Poison Package (PL no 6.299 / 2002) and its legislative opponent PNaRA (PL no 6.670/16).
\end{abstract}

Keywords: Food and nutrition security. Agribusiness. Pesticidis.

Data de submissão: 18/09/2018

Data de aceitação: 21/06/2019

\title{
SUMÁRIO
}

INTRODUÇÃO 1. O AGRONEGÓCIO NO BRASIL 2. ALIMENTAÇÁO ADEQUADA 3. SEGURANÇA ALIMENTAR E NUTRICIONAL NO MUNDO 4. AGROTÓXICO 4.1. O prejuízo para saúde humana 4.2. As indústrias que fabricam o veneno 5. PL DO VENENO (LEI No 6.299/02) 5.1. Produção orgânica e incentivo fiscal 6. PNARA (PL No 6.670/16). CONCLUSÃO

\section{INTRODUÇÁO}

Embora a Declaração de Estocolmo (Conferência das Naçôes Unidas de 1972) já tivesse estabelecido o meio ambiente sadio como direito fundamental da humanidade, no Brasil foi o Texto Constitucional de 1988 que veio tutelar o meio ambiente equilibrado, como direito e dever de todos (art. 225). Se o meio ambiente é de todos, tanto humanos quanto não-humanos o possuem. Até porque, meio ambiente não é somente o verde e o azul. Meio ambiente é fauna, flora, humanos, não-humanos, todos inseridos num contexto único e planetário, indissociável, difuso, impossível de individualizar e sem limites fronteiriços.

Em junho de 1992, a Conferência das Naçóes Unidas sobre o Meio Ambiente e o Desenvolvimento - ECO-92- (realizada no Rio de Janeiro), também conhecida como Cúpula da Terra, iniciou amplo debate conceitual do termo desenvolvimento sustentável. Até os dias atuais, ainda soa como algo fictício, encontrando dificuldades operacionais no lucro e na irresponsabilidade.

Apesar de já existir um arcabouço legislativo mínimo e amplo debate sobre como proteger o meio ambiente sem impedir o desenvolvimento econômico, países emergentes 
que possuem base econômica no agronegócio, como o Brasil ${ }^{1}$, sucumbem-se ao poder econômico para manter um sistema defasado e arcaico ambientalmente.

A Segurança Alimentar e Nutricional ultrapassa a questão da "quantidade" para ocuparse também com a "qualidade" dos produtos alimentícios. O Pacote do veneno (PL n ${ }^{\circ}$ 6.299/2002) vem trazer holofortes para a utilização irresponsável e desenfreada do uso de agrotóxicos, enquanto a sociedade luta para combater o processo através da Política Nacional de Redução de Agrotóxicos (Pnara).

\section{O AGRONEGÓCIO NO BRASIL}

O modelo de produção e preservação ambiental dos países emergentes gira em torno do agronegócio, principalmente da monocultura que utiliza grande quantidade de agrotóxico na lavoura. Ao contrário dos países desenvolvidos, como EUA e a maioria dos países do continente europeu, que já proíbem em larga escala o uso de substâncias químicas comprovadamente venenosas à saúde humana e ao meio ambiente.

Os países que utilizam como medidor apenas os impactos positivos do agronegócio na balança comercial e no PIB, como Brasil e Chile, não consideram os efeitos maléficos e gastos econômicos com a saúde e a devastação ambiental. Há uma ilusão de que parcela dos milhóes que contabilizam o PIB brasileiro é lucro produzido pelo agronegócio, pois além dos gastos com a saúde pública ainda há as perdas financeiras com incentivos e isençóes fiscais para facilitar a importação, uso e comércio destes produtos.

O Brasil é o terceiro maior produtor de alimentos do mundo. Este enorme celeiro mundial é também o número um em utilização de agrotóxico. Em um hectare de soja hoje se utilizam 12 litros de agrotóxico, quase o dobro de 10 anos atrás. Os grandes fornecedores dominam o mercado de agrotóxicos, de sementes e de medicamentos, cuja utilização é justamente no combate dos efeitos destes venenos no organismo humano, é um ciclo lucrativo. Normalmente as mesmas empresas que fabricam a semente, fabricam o medicamento e o agrotóxico, como a Bayer.

\footnotetext{
1 Este artigo é resultado de conclusōes obtidas no estágio Programa de Intercâmbio do Bloco de Defensores Públicos Oficiais do MERCOSUL (BLODEPM), denominado Pasantía, realizado no Chile, nas cidades de Santiago e Valparaíso, no período de 4 a 8 de Junho de 2018, onde formou-se um comité técnico composto por representantes da Defensoría Penal Pública de Chile, da Agencia Chilena de Cooperación Internacional para el Desarrollo - AGCID e de alguns membros das Defensorias Públicas Brasileiras, dentre as quais, a autora como representante da Defensoria Pública da União (DPU), Processo SEI n. 08038.002263/2018. Sendo participante do Grupo de Trabalho de Segurança Alimentar e Nutricional (GSAN) da DPU, a autora sintetizou seus conhecimentos através deste trabalho.
} 
O Brasil é o maior criador de gado bovino do planeta, existem mais cabeças de gados no país que pessoas. ${ }^{2}$ A produção de cereal é uma das maiores do mundo, tanto para alimentar os humanos como para alimentar o gado, aves e suínos. Há grande produção de açúcar, etanol, madeiras, frutas, algodão, arroz, feijão, milho e soja. Em toda a cadeia produtiva há riscos sanitários e dano ambiental, com o uso de "químicos dependentes" (herbicida, inseticida, fungicida). Desde o desmatamento, passando pelo transporte, armazenamento, pecuária, agricultura até a industrialização. Pisciculturas são construídas em meio a plantaçóes de soja, milho e algodão, contaminando-se pelo solo e pela pulverização ${ }^{3}$.

O agrotóxico cria uma cadeia de contaminação direta e indireta, contamina-se o produto agrícola, o trabalhador rural que o manuseia, os moradores que residem próximo ao local, principalmente com pulverizaçóes, o animal que se alimenta destes produtos, o ser humano que se alimenta da carne do animal e do produto agrícola, o solo e o lençol freático, o produto industrializado e as chuvas que são provenientes de água que evaporam com material tóxico. Além do processo produtivo, utilizam-se agrotóxico para homogeneizar o amadurecimento da soja e outros cereais, especialmente a transgênica (dessecantes como Paraquat ou Diquat, extremamente tóxicos aos rins e pulmóes) $)^{4}$.

O modelo produtivo de monocultura brasileira baseado em latifúndios é arcaico, insustentável e utiliza-se de técnicas obsoletas, postas em desuso em países industrializados. Uma herança de sesmarias que privilegia a concentração de renda, porque muitas terras estão nas mãos de poucas pessoas. Este modelo já vem sendo debatido por impedir a erradicação da pobreza e não resolver o problema da fome, já que em época de grande produção prevalece a lei da oferta e da procura. Para não perder valor na alta produção, os produtos são jogados fora pelo produtor para elevar o preço. Além do que, são destinadas principalmente à exportação, deixando o mercado interno desabastecido, nas mãos de pequenos agricultores da economia familiar. $\mathrm{O}$ brasileiro paga internamente mais pelo quilo do café nacional do que o estrangeiro paga lá fora.

A industrializaçáo brasileira recebeu enormes incentivos fiscais em 1965 por meio do

2 A Organização Mundial de Saúde (OMS) classificou as carnes processadas como carcinógeno do grupo 1, o mesmo que inclui o Tabaco, amianto e plutônio. Nos EUA, 1 a cada 3 dólares gastos com tratamentos de saúde estão voltados ao combate do diabetes. Já existem inúmeras pesquisas que relacionam o desenvolvimento de diabetes e câncer com o consumo em excesso de proteínas de origem animal. $\mathrm{O}$ documentário norte-americano "What the Health" alerta que as indústrias alimentícias possuem estreita ligaçáo com as pesquisas pagas que escondem a nocividade de alguns produtos e substancias utilizadas como alimento. A Mc Donald's, a Coca Cola e a indústria de carne como um todo investe pesado em propagandas de promoção de seus produtos e ganha apoio de bancadas ruralistas com poderoso lobbyng no Congresso Nacional. What the Health. Documentário. Disponível em https://www.youtube.com/ watch?v=NoYINMgImGs, 2017. Acesso em 9/9/18.

3 "É importante dizer, este um bilhão de litros do produto formulado, comprado nas casas da lavoura, que serão diluídos, em média, na proporção de um para cem litros de agua. Quer dizer, temos cem bilhôes de calda toxica, pulverizados nas lavouras de soja, de milho, de algodão, de cana, nas nossas hortaliças, no feijáo, no arroz. Cem bilhóes de litros de calda toxica, todo ano. Toxica vai parar nos alimentos, e a outra parte, vai para onde? Penetra no lençol freático. Uma parte evapora e fica no ar, para depois se condensar e descer na chuva". PIGNATI, Wanderlei. Agronegócio, agrotóxicos e saúde. In: OLIVEIRA DE SOUZA, Murilo Mendonça (Org). Agrotóxicos - violaçôes socioambientais e direitos humanos no Brasil Anápolis: Editora Universidade Estadual de Goiás, 2016, pags 17 a 45.

4

Ibid. 
Sistema Nacional de Crédito Rural (SNRC). A facilidade do crédito acabou prejudicando os pequenos agricultores em detrimento dos grandes exportadores monocultores. Em meados da década de 90, criou-se o Programa Nacional de Fortalecimento da Agricultura Familiar (Pronaf), para diversificar a produção que realmente atende o mercado interno, que alimenta o brasileiro, por meio da economia familiar. Mas não teve o sucesso almejado. Com o pacote tecnológico campestre do SNRC chegaram os agrotóxicos sem nenhuma legislação reguladora até final da década de 80 quando veio a Lei no 7.802/89 (Lei dos Agrotóxicos).

Em outros paises em desenvolvimento como o Chile, o sistema não foi tão diferenciado. Nos últimos anos, a tecnologia cresceu notadamente graças ao impulso dado às grandes companhias estrangeiras como a Monsanto, produtora de produtos químicos como agrotóxicos e sementes, por meio da aquisição da Seminis Vegetables Seeds, que iniciou suas operaçóes no mercado Chileno em 2005, e hoje fornece os mais variados insumos agrícolas.

As intoxicaçóes por pesticidas aumentaram o dobro nos últimos 10 anos e muitos casos não são relatados pelo receio dos trabalhadores de perderem seus empregos. Continua-se a utilizar na agricultura Chilena vários inseticidas altamente perigosos para saúde humana, como o Tamaron 600, distribuído pela Bayer, ou o Azinfos Metil, organofosforado que pertence ao grupo mais perigoso do nível $1 \mathrm{~b}$, dentre seus nomes comerciais o Gusathion $M$.

Quase os mesmos produtos tóxicos utilizados no Brasil são utilizados no Chile e ambos comercializam entre si produtos contaminados, o brasileiro come Salmáo e toma vinho chileno, enquanto o chileno toma café brasileiro contaminado.

\section{ALIMENTAÇÁO ADEQUADA (DHAA)}

Em 1994, o sociólogo Herbert de Souza, o Betinho, com o slogan "Quem tem fome tem pressa", criou a organizaçáo não-governamental "Ação da Cidadania Contra a Fome, a Miséria e pela Vida", no Rio de Janeiro. Betinho convocou a população em geral, empresários, ricos, classe média e imprensa, para fazerem uma cruzada para levar alimentos a quem não os tinha. Ao lançar esta campanha ele tentava minimizar os dados alarmantes da Food and Agriculture Organization (FAO), agência da ONU, que noticiava 32 milhóes de brasileiros sem ter o que comer. Quase um terço da população passava fome na década de 90 . Morriam 25 mil pessoas por dia vítimas da miséria e da pobreza. A cada 3,6 segundos alguém morria de fome no mundo.

No ano de 2000, o Brasil se classificou dentre os 25 países em desenvolvimento que atingiram as metas propostas pela $\mathrm{ONU}$, reduzindo pela metade a proporção de pessoas com fome e o número absoluto desta população de famintos. ${ }^{5}$ Betinho já falecido não viu seu mérito. Lamentavelmente, hoje, passados 20 anos, o país voltou a alcançar índices preocupantes de pobreza. O IBGE mostrou em abril de 2018, que após anos de avanço

FAO. State of Food Insecurity in the World. A Food and Agriculture Organization (FAO). Diponível em: <http://www.fao.org/3/a-i4037e.pdf>. Acesso em: 09 set. 2018. 
no combate à pobreza, houve um retrocesso durante a crise econômica brasileira dos últimos 3 anos, o número de pessoas em situação de extrema pobreza e fome no país passou de 13,34 milhóes em 2016, para 14,83 milhóes em 2017, um aumento de 11,2\% na pobreza absoluta do país. ${ }^{6}$

A fome é um dos maiores prejudiciais para economia e desenvolvimento de um país. Impacta diretamente nas relaçóes de emprego, na produtividade, no aprendizado e aumenta o índice de acidente de trabalho. Afeta o desenvolvimento físico e intelectual das crianças e afeta diretamente o rendimento e abandono escolar. A Defensoria Pública da União em inúmeros itinerantes nos rincóes do país, não raro se depara com as chamadas doenças de fome e baixa imunidade: anemia, hepatite, desnutrição, epilepsia e cegueira, Doenças comuns em determinadas regióes brasileira devido a carência de vitaminas e nutrientes, como ferro, iodo, zinco e vitaminas A e D. Doenças invisíveis que reduzem ou acabam com a capacidade laborativa do indivíduo.

"A anemia, sozinha, é capaz de reduzir o PIB de um país de 0,5\% a 2\%". Em 1998 havia 840 milhóes de pessoas desnutridas no mundo, das quais 799 milhóes vivem em países em desenvolvimento, 30 milhóes nos países em transição e 11 milhóes nos países industrializados. ${ }^{7}$ Observa-se que existe desnutrição mesmo em países desenvolvidos. Destruição causada menos pela fome e mais pela alimentação inadequada, com produtos de baixa ou nenhuma qualidade nutricional, a exemplo dos alimentos industrializados.

O consumo exagerado de produtos industrializados e fast foods, a má informação e doenças associadas à depressão tem gerado graves problemas de desnutrição bulímica, anorexia nervosa e obesidade. Com 25 milhóes de crianças e 250 milhóes de adultos obesos, a obesidade virou epidemia e problema de saúde pública. Este exagero apresenta prejuízos para saúde humana e para o orçamento do SUS, em razão de doenças periféricas como diabetes, pressão alta, problemas cardíacos e depressão. ${ }^{8}$ Sendo que a obesidade, embora configure excesso energético, também pode apresentar baixa de nutrientes.

"Direito Humano à Alimentação Adequada" (DHAA) foi uma expressão cunhada embrionariamente no Pacto Internacional dos Direitos Econômicos, Sociais e Culturais (Pidesc) de 1966, ratificado pelo Brasil em 1992 (Decreto legislativo no. 591/1992). Tem sua definição no artigo $2^{\circ}$ da Lei de Segurança Alimentar (Lei no 11.346/2006) que Criou o Sistema Nacional de Segurança Alimentar e Nutricional (Ssisan) ${ }^{9}$, como sendo:

\footnotetext{
6 VILLAS BOAS, B. Pobreza extrema aumenta $11 \%$ e atinge $\mathbf{1 4 , 8}$ milhóes de pessoas. Valor Econômico, 2018. Diponível em: https://www.valor.com.br/brasil/5446455/ pobreza-extrema-aumenta-11e-atinge-148-milhoes-de-pessoas. Acesso em :9 set. 2018.

CHAIM, C. Quem tem fome tem pressa. Isto É. 2002. Disponível em: <https://istoe.com. br/27047_QUEM+TEM+FOME+TEM+PRESSA>. Acesso em: 9 set. 2018.

8 BURITY, V. Direito humano à alimentaçáo adequada no contexto da segurança alimentar $\mathbf{e}$ nutricional, 2010.

9 O SISAN é integrado por um conjunto de órgãos e entidades da União, dos Estados, do Distrito Federal e dos Municípios e pelas instituiçóes privadas, com ou sem fins lucrativos, afetas à segurança alimentar e nutricional e que manifestem interesse em integrar o Sistema, respeitada a legislação aplicável. A Defensoria Pública da União faz parte do SISAN, sendo representada pelos membros do Grupo de Trabalho (GT) de Segurança Alimentar e Nutricional (GSAN).
} 
Art. 2‥ A alimentação adequada é direito fundamental do ser humano, inerente à dignidade da pessoa humana e indispensável à realizaçáo dos direitos consagrados na Constituição Federal, devendo o poder público adotar as políticas e açóes que se façam necessárias para promover e garantir a segurança alimentar e nutricional da população. ${ }^{10}$

A adoção das políticas para promover a segurança alimentar deverá levar em conta as dimensóes ambientais, culturais, econômicas, regionais e sociais. Se é um política pública e um direito fundamental do indivíduo, umbilicalmente ligado ao Princípio da Dignidade Humana (art. 10, III, CF) tem que ser protegido e promovido pelo Estado. Observa-se que o direito à alimentação está incluído no rol de direito social do art. $6^{\circ}$ do Texto Constitucional (EC 64/2010).

Para respeitar as dimensóes ambientais do Brasil, deve-se observar em cada comunidade e regiāo brasileira, os seguintes componentes:

- Disponibilidade (terras produtivas, recursos naturais disponíveis, como a água, produtos fornecidos na rede de comercio local);

- Adequação (preparação e consumo de acordo com a cultura, tradição, hábitos e padróes alimentares e de saúde, próprias ao consumo e sem riscos para saúde, desenvolvidos através de técnicas sustentáveis e sem dano ambiental);

- Acessibilidade física (idosos, crianças, lactentes, portadores de necessidades especiais, doenças terminais, presos, vítimas de calamidades e risco social);

- Acessibilidade econômica (financeira) e a estabilidade no fornecimento. ${ }^{11}$

Portanto, Direito à Alimentação Adequada pressupóe a realização de outros direitos consagrados no texto constitucional como meio ambiente equilibrado, saúde, educação, informação, para que se promova os objetivos fundamentais da nação, (I - construir uma sociedade livre, justa e solidária; II - garantir o desenvolvimento nacional; III - erradicar a pobreza e a marginalização e reduzir as desigualdades sociais e regionais; IV - promover o bem de todos, sem preconceitos de origem, raça, sexo, cor, idade e quaisquer outras formas de discriminação).

\section{SEGURANÇA ALIMENTAR E NUTRICIONAL NO MUNDO}

O homem era nômade e com o tempo fixou-se na terra, desenvolvendo a agricultura e interferindo no meio ambiente. A erosão do solo já preocupava Platão no ano 400 a.C.

$10 \quad$ Lei Orgânica de Segurança Alimentar e Nutricional - Lei 11.346 de 15 de setembro de 2006. Disponível em: http://www.abrandh.org.br/downloads/losanfinal15092006.pdf.Acesso em: 10/9/18.

11 Op. cit. BURITY, Valéria. 
e eliminou a civilização Maia em 900 d.C. ${ }^{12}$ Os instrumentos que antes eram manuais, como pá e enxada, evoluiu ao arado, carro de boi e charrua na Idade Média, aumentando a produção agrícola.

Nos fins do século XIII, a degradação dos recursos naturais e do solo e o superpovoamento levou o homem a uma crise famélica que o tornou vulnerável às epidemias, como a peste bubônica, tuberculose e varíola. "A peste negra dizimou grande parte da população entre 1347 e 1351, o que ocasionou a regressão do desenvolvimento agrícola, industrial, comercial e artesanal". ${ }^{13}$ Com a revolução industrial (século XVII), a produção de máquinas agrícolas aumentou novamente a produtividade do campo.

As práticas de fertilização orgânicas foram abandonadas em 1840, com a descoberta do químico alemão Justus Von Liebig, de que a nutrição das plantas se dava por meio de substancias químicas presentes no solo, que poderiam aumentar a produção, caso fosse acrescidos estas substancias, nasceu assim o mercado de fertilizantes químicos.

Após a 20 Guerra Mundial, as indústrias químicas, bélicas e farmacêuticas desenvolveramse bastante para atender os interesses da guerra e do pós-guerra com a reconstruçáo dos países destruídos. Os fertilizantes e agrotóxicos até entáo utilizados como explosivos e armas químicas, passaram a ser utilizados na agricultura (explosivos transformaram-se em adubos sintéticos, gases em agrotóxicos e tanques de guerra em tratores). ${ }^{14}$

Temendo boicotes, cercos e embargos militares e políticos, alguns países europeus começaram a utilizar o termo segurança alimentar durante a Primeira Guerra Mundial (1914-1918), porém restrito-o à ideia de segurança nacional. A partir da Segunda Guerra Mundial (1939-1945), especialmente após a criação da ONU e da FAO (1945), o termo passa a estar relacionado à insuficiência passou a ser relacionado na disponibilidade de alimentos.

Na década de 60 e 70, deflagrada pelo Revolução Industrial, iniciou-se mundialmente a Revolução Verde. Um modelo de aumento de produção agrícola mundial para solucionar a fome no mundo. Aumentou a produção, a poluição e as mudanças climáticas. A Revoluçáo Verde baseava-se na utilização de sementes geneticamente melhoradas e uso de fertilizantes e agrotóxicos, principalmente nos países em desenvolvimento. A Índia foi o cenário experimental com um enorme aumento na produção de alimentos. Em poucos anos verificou-se que a fome não foi erradicada e o meio ambiente sofreu impactos devastadores com reduçáo da biodiversidade, menor resistência a pragas, êxodo rural e contaminação do solo e dos alimentos com agrotóxicos. ${ }^{15}$

O Brasil também foi adepto da Revolução Verde na década de 70, durante a ditadura 1997. p. 256.

13 COSTA, G. S. V. da. Da regulamentaçáo dos agrotóxicos. In: Âmbito Jurídico, Rio Grande, XV, n. 103, ago 2012. Disponível em: <http://ambito-juridico.com.br/site/index. php/?n_link=revista_artigos_ leitura\&artigo_id $=11864 \&$ revista_caderno=5>. Acesso em: 9 set. 2018 .

$14 \quad$ Ibid.

15 Op. cit. BURITIY, Valéria. 
militar. O governo adotou a monocultura, modernização do campo com isençóes fiscais para instalação de indústrias químicas produtoras de agrotóxicos, uso de variedades genéticas e crédito rural para aquisição de fertilizantes e maquinário. Em 1975, o Plano Nacional de Desenvolvimento (PND), obrigava o agricultor a comprar tais produtos para obter recursos do crédito rural. Investiu-se na propaganda dos fertilizantes. Houve um enorme impulso na produção de soja, ocasionando excedente de produçáo com queda de preços. Para controlar o preço, o produtor jogava o alimento fora. Não havia uma política de armazenamento estratégico.

Nos EUA, iniciou-se movimentos ambientalistas com a publicação do livro "The Silent Spring" (Primavera Silenciosa) da pesquisadora americana Rachel Carson em 1962. ${ }^{16}$ No livro a autora expôs os perigos do uso de pesticidas (DDT), questionando a vulnerabilidade e crença do homem moderno no progresso tecnológico. O governo estadunidense de John Kennedy, por meio de seu comitê científico, investigou as denúncias feitas no livro, culminando na proibiçãa de uso do pesticida naquele país. Mas o grande mérito do livro foi a repercussão junto à população, pelo fato de ter sido lançado em edição de bolso nos EUA, não ficando restrito à academia, e ainda o surgimento da inversão do ônus da prova na questão ambiental. Passou a ser responsabilidade dos fabricantes provar que seus produtos eram seguros, o que lógico, as indústrias químicas não conseguiram fazer.

Em 1972, um grupo de pesquisadores, empresários, políticos e cientistas de todo o mundo, conhecido como Clube de Roma, encomendaram um relatório (Meadows) para o Massachusetts Institute of Tecnology (MIT), devido à crise ecológica deflagrada e suas consequências para a área comercial, visando obter uma visão sistêmica dos problemas. O relatório denominou-se "os limites do conhecimento" ${ }^{17}$. No mesmo ano, efetuouse o primeiro acontecimento ambiental estatal, a Primeira Conferência da ONU sobre o Meio Ambiente Humano, Conferência de Estocolmo, que fixou princípios comuns para preservação ambiental e desenvolvimento socioeconômico equitativo (eco desenvolvimento).

Em 1974, aconteceu a Conferência Mundial de Alimentação, discutindo e redimensionando o conceito de segurança alimentar no final da década de 80, que passou a incorporar também "a noção de acesso a alimentos seguros (não contaminados biológica ou quimicamente); de qualidade (nutricional, biológica, sanitária e tecnológica), produzidos de forma sustentável e equilibrada, com acesso à informação". ${ }^{18}$

Passa-se a utilizar o termo Segurança Alimentar e Nutricional (SAN), agregando-se o

$16 \quad$ Rachel Louise Carson, escritora, cientista e ecologista norte-americana, demonstrou cientificamente que o DDT, inventado por um prêmio Nobel, destruía de imediato inúmeras espécies de insetos, mas acumulava-se no sistema gorduroso dos animais, causando extermínio de espécies inteiras, câncer e mutação genética. Para maior alcance popular a autora utilizou-se do recurso da fábula para contar a história de uma cidade fictícia que foi dizimada pelo pesticida, tendo silenciado todos os pássaros daquela primavera.

17 Em 1983, a Assembleia Geral da ONU cria a Comissão para o Meio Ambiente e Desenvolvimento, presidida pela Primeira Ministra da Noruega Gro. Harlem Brundtland, com a incumbência de pesquisar os problemas ambientais globais, dando origem ao Relatório Brundtland de 1989 (Our Common Future), onde se cunhou o conceito de "desenvolvimento sustentado", que foi trazido ao Brasil na ECO 92. 
aspecto nutricional e sanitário na Conferência Internacional de Nutrição (1992) e Cúpula Mundial da Alimentação (1996), ambas realizadas pela FAO em Roma. "A partir de então, de forma progressiva, a SAN começa a ser entendida como uma possível estratégia para garantir a todos o Direito Humano à Alimentação Adequada (DHAA).” 19

\section{AGROTÓXICO}

Segundo a Organização Mundial de Saúde (OMS) os Agrotóxico e afins (inseticidas, acaricidas, bacteriostatos, fungicidas e herbicidas defensivos agrícolas, pesticidas, praguicidas, biocidas, agroquímicos) são produtos químicos nocivos à saúde humana que são utilizados no controle e prevenção de pragas, principalmente na agricultura. No Brasil o termo é definido na Lei n. ${ }^{\circ} 7.802$ de 11 de julho de 1989 (Lei do Agrotóxico), regulamentada pelo Decreto n. ${ }^{\circ} 4.074 / 2002$, que excluiu como afins os fertilizantes e hormônios utilizados em animais, muitas vezes também produtos tóxicos ao organismo humano.

Art. 2० Para os efeitos desta Lei, consideram-se:

I - agrotóxicos e afins:

a) os produtos e os agentes de processos físicos, químicos ou biológicos, destinados ao uso nos setores de produção, no armazenamento e beneficiamento de produtos agrícolas, nas pastagens, na proteção de florestas, nativas ou implantadas, e de outros ecossistemas e também de ambientes urbanos, hídricos e industriais, cuja finalidade seja alterar a composição da flora ou da fauna, a fim de preservá-las da ação danosa de seres vivos considerados nocivos;

b) substâncias e produtos, empregados como desfolhantes, dessecantes $^{20}$, estimuladores e inibidores de crescimento;

II - componentes: os princípios ativos, os produtos técnicos, suas matérias-primas, os ingredientes inertes e aditivos usados na fabricação de agrotóxicos e afins

$19 \quad$ Ibid. A Lei de Segurança Alimentar, Lei no 11.346/2016 (LOSAN), em seu artigo 4º, esclarece a abrangência do termo segurança Alimentar Brasileira.

20 Desfoliante e dessecante são substancias químicas utilizadas na lavoura. O Desfoliante induz a queda prematura das folhas, já foi utilizado na guerra como arma química, a exemplo do "agente laranja" utilizado na guerra do Vietname na década de 60 pelos Estados Unidos, criando uma geraçáo de crianças com deformação em braços e pernas. O Dessecante, absorve água e umidade em geral, utilizado em várias situaçôes na indústria e lavoura. Os mais sílica gel, sulfato de cálcio, cloreto de cálcio e argila. Um conhecido dessecante natural é o sal, utilizado na conservação de alimentos como carne. 
Há uma classificação taxonômica dos agrotóxicos, de acordo com sua nocividade que inicia-se no nível 1 , rótulo vermelho extremamente perigoso e termina no nível 04 , rótulo verde. ${ }^{21}$ Muitos agrotóxicos do primeiro nível são proibidos no mundo e no Brasil desde 2009, mas são comercializados clandestinamente. O diclorodifeniltricloroetano (DDT), uma síntese do cloral e clorobenzeno, foi muito utilizado durante a Segunda Guerra Mundial e no controle da malária em todo mundo. Sua toxidade e danos ambientais foram alertados no livro de Rachel Carson, como já mencionado em item anterior.

O DDT foi bem eficaz na década de 70 no Brasil combatendo pragas, no entanto, desenvolveu nas mesmas pragas uma enorme resistência biológica que prejudicou enormemente a agricultura e o meio ambiente, pois elevou ao dobro o consumo de agrotóxicos no país nos últimos 10 anos. Os organofosfatos (Sarin, Soman, Tabun) vieram com força total na substituição do DDT, porque eliminam os insetos diretamente e também são absorvidos pelo vegetal que se torna tóxico ao próprio inseto, porém, pelo mesmo motivo, são mais contaminantes, porque facilmente absorvidos pelo lençol freático.

Existe grande problema de insuficiência na fiscalização e controle no manuseio doa agrotóxicos. A classificação taxonômica seria de grande relevância para a populaçáo que manuseia o produto se a maioria não fossem pessoas leigas ou de baixa escolaridade que não leem rótulo. A falta de etiquetagem apropriadas, expondo o risco dos químicos e dos transgênicos à saúde humana e ao meio ambiente como um todo é uma realidade.

Ademais, pequenos agricultores não utilizam equipamentos de segurança e utilizam métodos perigosos de difusão dos agrotóxicos. Os pequenos agricultores usam pulverizadores de mochila (extremamente perigosos) e os grandes agricultores utilizam pulverizadores em avióes, em desacordo com Instruçóes Normativas do Ministério da Agricultura, Pecuária e Abastecimento (MAPA), que estabelece um limite mínimo de 500 metros longe de qualquer área habitada, córregos, criaçóes e escolas.

Estas pulverizaçóes aéreas têm causado acidentes graves como o caso da escola rural de

21 "O agrotóxicos podem ser divididos em inseticidas, herbicidas e fungicidas. O inseticida são utilizados para exterminar insetos, destruindo ovos e larvas principalmente. Os herbicidas são usados na agricultura para o controle de ervas daninhas. Já os fungicidas destroem ou inibem a ação dos fungos que geralmente atacam as plantas. Os inseticidas formam 3 grandes grupos, os organoclorados, os organofosforados e carbamatos e piretrinas. Os herbicidas têm como grupos mais importantes Paraquat, clorofenoxois e dinitrefenóis. Quanto à finalidade os agrotóxicos podem ser classificados em: ovicidas (atingem os ovos dos insetos), larvicidas (atacam as larvas), acaricidas (para ácaros) ou formicidas (atacam formigas). Os agrotóxicos podem agir através da ingestão (a praga ingere a planta com o produto), microbiano (o produto contém microorganismos que atacarão a praga ou o agente causador da doença) e por contato (ao tocar o corpo da praga o produto já faz efeito). Dentre os pesticidas utilizados no setor agrícola, destacam-se os seguintes: Aldrin, utilizado no controle de pragas do solo (principalmente cupins), no milho, no algodão e na batata por pulverização. Clordano, inseticida utilizado em vários tipos de lavoura e contra cupins. Dieldrin, inseticida usado em pomares de frutas, no solo e no cultivo de sementes. Endrin, raticida e inseticida usado na cultura de algodáo, arroz e milho. Heptacloro, inseticida usado contra insetos do solo, cupins e saúvas. Hexaclorobenzeno, fungicida e, também, subproduto na fabricação de defensivos e contaminadores em outros agrotóxicos. Mirex (MR), um dos pesticidas mais estáveis e persistentes, é um inseticida usado para o combate de saúvas, corta-folhas e cupim segador; e Toxaphene (MR), inseticida usado especialmente contra carrapatos, acarinos e larvas e no algodão, composto de 670 produtos químicos. ” Op. cit. Costa, Geovana Specht Vital. 
Rio Verde, Goiás, Pontal dos Buritis, cercadas de plantação de milho, onde um avião pulverizou dezenas de crianças no ano de 2013, cuja responsabilização ficou apenas no âmbito da negligência. ${ }^{22}$

Estudos da Anvisa apontam que o pimentáo é o alimento mais contaminado por agrotóxico (92\% dos pimentóes pesquisados estava inapropriado ao consumo). Morango (63\%), pepino (57\%), alface (54\%), cenoura (49\%), abacaxi, beterraba e mamão passam dos 30\%, além do alimento in natura, também os processados estão contaminados (leite, derivados e carnes processadas ${ }^{23}$. O Programa de Análise de Resíduo de Agrotóxico em Alimentos (Para), do Ministério da Saúde, coordenado pela Anvisa, fez uma pesquisa em 2012 recolhendo amostras em mais de mil supermercados em todo o país e detectou que apenas um terço dos alimentos não possuem resíduos de agrotóxicos além do permitido. $\mathrm{Na}$ pesquisa não constaram os agrotóxicos a base de glifosato, cujo princípio ativo é o Roundap, o que provavelmente teria demonstrado que nos alimentamos com $100 \%$ de vegetais contaminados. ${ }^{24}$

Os países da Organização para Cooperaçáo e Desenvolvimento Econômico (OCDE), dentre os quais EUA, China, União Europeia, Costa Rica e Bolívia, tradicionalmente conhecidos por utilizarem muito agrotóxicos, já proibiram bastante o uso de químicos que ainda são utilizados no Brasil. Mais de $70 \%$ dos agrotóxicos proibidos no mundo ainda são utilizados aqui. É como se cada brasileiro consumisse 5 litros de veneno por ano.

Desde 2007 e principalmente durante a durante a Conferência Internacional sobre a Gestão de Produtos Químicos, em 2015, a FAO vem elaborando recomendaçóes com iniciativas de reduzir o risco e uso de agrotóxicos no mundo, recomendando a proibição progressiva destes químicos.

\footnotetext{
22 TALGA, Dagmar. Pontal do Buriti. Brincando na chuva de veneno. Diretora Dagmar Talga, 2013. Disponível em: <https://www.youtube.com/watch?v=qHQdWwZcGlg>. Acesso em: 9 set. 2018.

A responsabilização pelo uso inadequado de agrotóxico abrange as três esferas de atuação e possui inúmeros normativos que são pouco eficazes no combate ao dano, principalmente porque náo repara a saúde humana e o meio ambiente danificado, senão, quanto muito, atribui responsabilidades. A responsabilidade civil está no Texto Constitucional de 1988, em seu art. 225, $\$ 3^{\circ}$. A Lei 6.938/81, em seu artigo 14 atribuiu responsabilidade a uma cadeia de profissionais envolvidos na comercializaçáo do agrotóxico, mas do agente financiador. A responsabilidade Penal está no artigo 56 da Lei de Crimes Ambientais, (Lei 9.605/98), e a responsabilização administrativa segue as normas do art. 43 do Decreto 3.179/99 dentre outros. Quanto as propagandas comerciais, a Lei $\mathrm{n}^{\circ} .7 .802 / 89$ determina que em qualquer meio de comunicaçáo, seja clara a advertência "sobre os riscos do produto à saúde dos homens, animais e ao meio ambiente", sendo aplicado a mesma lei que regula propaganda de cigarro e bebidas, Lei 9.294/96 (Decreto 4078/02 c/c art. $220 \$ 4^{\circ}$ da CF). A Convençáo n. ${ }^{\circ} 184$ da OIT (Relativa à segurança e saúde na Agricultura) incentivou Normas Regulamentadoras, como a NR 31(NR31) do Ministério do Trabalho e Emprego (MTE), que também trata do tema.

23 ROSSI, M. El país. São Paulo, 2015. Disponível em: <https://brasil.elpais.com/brasil/2015/04/29 /politica/ 1430321822_851653.html?rel=mas>. Acesso em: 9 set. 2018.

24 TALGA, D. O. e TALGA, J. V. B. O poder do agronegócio e a mídia:Analise a partir da pulverizaçáo aérea de agrotóxico sobre a escola municipal Sáo Jose do pontal, in OLIVEIRA DE SOUZA, Murilo Mendonça (org.) Agrotóxicos - violaçóes socioambientais e direitos humanos no Brasil. Anapolis: Editora Universidade Estadual de Goiás, 2016, pag 137-170.
} 


\subsection{O prejuízo para saúde humana}

Dados do IBGE de 2013, "mostram que a cada US\$ 1 (um dólar) gasto na compra de agrotóxicos, o Sistema Único de Saúde (SUS) gasta R \$ 1,28 com a saúde de camponeses intoxicados." ${ }^{25}$ Entre os anos de 2007 a 2014 o Brasil tinha 1 morte a cada 2 dias e meio em razão de contaminação por produtos agrotóxicos, 8 intoxicaçóes por dia, mais da metade crianças. ${ }^{26}$

Organoclorados permanecem até 30 anos no meio ambiente. São absorvidos por via oral, respiratória e dérmica, e atingem o sistema nervoso central e periférico, provocando câncer. Os carbamatos ainda atingem os músculos do cérebro e glândulas. Organofosforados, como o Tamaron causam Polineuropatia retardada (fraqueza progressiva e ataxia das pernas, podendo evoluir até uma paralisia flácida); conhecida como Síndrome Intermediária ${ }^{27}$ (paralisia que afeta principalmente os músculos flexores do pescoço, músculos da perna e respiratórios, diarreia intensa, e perda de potássio, depressão respiratória e morte) e efeitos comportamentais diversos (insônia, ansiedade, dificuldade de concentração, apatia, irritabilidade, depressão, esquizofrenia, falhas de memória). Os sintomas mais comuns identificados são dores de cabeça, tonturas, náuseas, vômitos, sudorese intensa, salivação, lacrimejamento e constrição pupilar, fraqueza, contração muscular, convulsóes, podendo progredir ao coma. As piretrinas (alergizante) causam crises de asma e bronquite. Paraquat, causa lesóes no rim e fibrose no pulmão.

"Segundo estudos, os municípios que mais usam organofosforados no Rio Grande do Sul são os que apresentam os maiores índices de suicídio no estado". ${ }^{28}$ Regiōes com monoculturas (principalmente de soja e milho), onde o agronegócio é mais intenso, são também os que apresentam mais índices de casos de envenenamento, má formação genética, câncer e problemas neurológicos, endócrinos e imunológicos, como Goiás (Rio Verde) e Mato Grosso (Rondonópolis, Sinop, Lucas do Rio Verde e Tangara da Serra). ${ }^{29}$

25 Op. cit. TALGA, D. O.

26 BOMBARDI, L. M. Atlas “Geografia do uso de agrotóxicos no Brasil e conexóes com a União Europeia”. FFLCH USP. São Paulo, 2007. Disponível em: <www.larissabombardi.blog.br/atlas>. Acesso em: 9 set. 2018.

27 (...) Outro quadro neurológico grave, desencadeado por exposiçóes aos OPs, foi identificado mais recentemente, e passou a ser conhecido como "síndrome intermediária". A Síndrome Intermediária (SI) caracteriza-se pela acentuada fraqueza dos músculos respiratórios, e diminuição da força dos músculos do pescoço e das extremidades proximais dos membros. Esses sintomas aparecem algumas horas após o início dos sintomas de hiper-estimulação colinérgica (intoxicação aguda). O comprometimento respiratório na SI, se não houver pronto atendimento em hospitais equipados com aparelhos de respiração assistida, pode levar à morte (...). Idid. BOMBARDI, Larissa Mies.

28 Op. cit. Costa, Geovana Specht Vital.

29 CARNEIRO, Fernando Ferreira. Dossiê ABRASCO: um alerta sobre os impactos dos agrotóxicos na saúde. In: CARNEIRO, Fernando Ferreira (org). Rio de Janeiro: EPSJV; São Paulo: Expressão Popular, 2015. Disponível em: content/uploads/2013/10/DossieAbrasco_2015_web.pdf>. Acesso em: 9/9/18. Nas amostras de leite materno de mulheres moradoras da cidade de Lucas do Rio Verde-MT, 100\% do material analisado apresentavam algum tipo de composto químico toxico, incluindo o veneno diclorodifenilticloroetano, conhecido como DDT, proibido desde 2009 no Brasil e desde 1972 nos EUA. Também foi encontrado nas amostras o agrotóxico Endosulfan, hoje proibido no Brasil.” Op. Cit. TALGA, Dagmar Olmo. 
É assustador ver a quantidade de cidades do interior do Brasil que inauguraram hospitais de câncer na última década, como Umuarama no Paraná, aliás, o Paraná se destaca como a capital brasileira que mais teve notificaçóes com casos de envenenamento, quase o dobro da média nacional dos últimos anos. ${ }^{30}$

Os agrotóxicos não causam somente problemas de saúde de forma aguda, onde as maiores vítimas são a população rural e ocupacional, causam graves problemas crônicos também na população urbana e não ocupacional, contraídos ao longo dos anos através da alimentação e água contaminada. Atraso no desenvolvimento das crianças, doenças neurológicas, como doença de Parkinson, esclerose lateral amiotrófica e Alzheimer, desenvolvimento de alguns tipos de câncer, como leucemia, próstata, mama e linfoma de Hodgkin, efeitos deletérios no nível citogenético e na capacidade reprodutiva, efeitos teratogênicos, alteraçôes neurocomportamentais e cognitivas, efeitos endócrinos, abortos espontâneos, malformaçóes congênitas. ${ }^{31}$

\title{
4.2 As indústrias que fabricam o veneno
}

Há um ditado atribuído ao médico Paracelso do século popular XVI, afirmando que "a diferença entre o remédio e o veneno é a dosagem”. As mesmas empresas químicas que produzem o agrotóxico, produzem as sementes geneticamente modificadas que necessitam cada vez mais de agrotóxico e ainda produzem o medicamento para combater as doenças causadas por estes agrotóxicos, ou seja, "a doença é um ótimo negócio no capitalismo", explica Thomas Toledo, quanto ao funcionamento deste ciclo macabro de envenenamento: ${ }^{32}$

\begin{abstract}
"A Bayer compra a Monsanto, formando um truste. A parte Monsanto joga veneno nas frutas, verduras, legumes e cereais. As pessoas consomem e ficam doentes. Aí entra a Bayer com o remédio. Ela náo cura, mas a prolonga o tratamento para ganhar mais. Como tem patentes e monopoliza o mercado, ela coloca o preço que quiser. Da mesma forma que a agricultura com veneno é subsidiada pelo governo, o sistema público de saúde também pagará pelo tratamento. O político bancado por essas empresas trabalha para tirar as restriçóes ao veneno e para encarecer o custo dos orgânicos. Com aumento no número de doentes, ele promete construir hospitais. $\mathrm{O}$ povo vota e ele trabalha para as empresas. Assim, o Estado gira essa roda de envenenamento, doença, político vendido.”
\end{abstract}

No documentário "O Mundo Segundo a Monsanto"(Le monde selon Monsanto, 2008), de Marie-Monique Robin, há um alerta sobre como grandes corporaçóes de empresas

\footnotetext{
30 PIGNATI, W. Os efeitos dos agrotóxicos na saúde humana. UFMT Seminário internacional contra os agrotóxicos e pela vida Fórum estadual de combate aos agrotóxicos do Paraná 2012.Disponível em: http://www.meioambiente.mppr.mp.br/arquivos/File/ EFEITO_DOS_AGROTOXICOS_PIGNATI . pdf. Acesso em: 8/6/2006.

31 Op cit. QUEZADA, María Teresa Muñoz

32 TOLEDO, T. A doença é um ótimo negócio no capitalismo. Disponível em: https:// caviaresquerda.blogspot.com/2018/07/a-doenca-e-um-otimo-negocio-no.html.Acesso em 9/9/18.
} 
dominam a agricultora global através de práticas de pressão política e econômica, manipulação e controle de mercado e de dados científicos, tornando-se o mais lucrativo e seguro do mundo. A produção de fitofarmacéuticos, fitossanitários, defensivos agrícolas, agrotóxicos em geral decorrem prioritariamente de interesses lucrativos e não de melhoria de alimentos para acabar com a fome no mundo. Ao contrário, a história nos mostrou que nem sempre a tecnologia veio reduzir a fome e a desigualdade social.

As sementes são alteradas geneticamente e a cada vez necessitam de quantidades maiores de agrotóxicos para controlar as pragas cada vez mais resistentes. A população fica cada vez mais doente e a venda de medicamentos aumenta. É uma compra casada, "os agricultores tem que pagar pelas sementes e estas implicam na compra de um determinado agrotóxico, tornando-se assim não um modelo de produção, mas um modelo de domínio econômico". É impressionante a quantidade de farmácias que existem em Belo Horizonte (MG). Cada esquina, literalmente possui uma farmácia. É um mercado que não vê crise.

Seis grandes empresas transnacionais controlam mais de $80 \%$ do mercado agroquímico: Syngenta (Suiça), Dupont (Estados Unidos), Dow Chemical (Estados Unidos), Bayer (Alemanha), comprou a Monsanto (EUA), Novartis (Suiça), Basf (Alemanha) e Milenia (Holanda/Israel). ${ }^{33}$

A Monsanto da Bayer, a maior e mais conhecida, foi fundada nos EUA (1901), especializando-se em produção de produtos químicos, agropecuários e farmacêuticos. Seu carro chefe era o herbicida glifosato (Roundup). Fabrica também medicamentos e hormônios como aspirinas, Vanilina, aspartame, ácido sulfúrico e somatropina bovina $(\mathrm{BST})^{34}$ e o nocivo óleo Ascarel (PCB), utilizado em tintas, transformadores e lubrificantes hidráulicos. $\mathrm{Na}$ década passada, entrou no mercado de insumos agrícolas em geral como sementes geneticamente modificadas.

A história de sua constituição é assustadora. Indústria química alemã, inicialmente voltada para produção de tintas e corantes, integrava um cartel poderoso (IG Farben, juntamente com a BASF, Hoechst AG e outras) que doou dinheiro na campanha de Adolh Hitler, desenvolveu produtos utilizados pelo exército alemão e ainda produziu o gás Ziklon-B utilizado nas câmaras de extermínio. Seus medicamentos e vacinas foram testados em trabalhadores de suas fábricas. Cresceu bastante durante a Primeira Guerra Mundial produzindo gases tóxicos e explosivos.

Durante o Forum Social Mundial de 2005, realizado em Porto Alegre, a Action Aid publicou um relatório denunciando que a Monsanto era uma das empresas que mais estava contribuindo para fome no mundo, ao controlar grande parte do comércio internacional de alimentos e produtos agrícolas. ${ }^{35}$

\footnotetext{
33 Op. Cit. TALGA, Talga, Dagmar Olmo.

34 O somatropina bovina (BST), conhecido como hormônio do crescimento, é utilizado para aumentar a produção do leite nas vacas e já está proibida em diversos países do mundo por causar mastite e outras infecçóes nos animais e nos seres humanos.

35 ACTIONAID INTERNACIONAL.Power hungry six reasons to regulate global food corporations. 2005. Disponível em: https://www.actionaid.org.uk/sites/default/files/doc_lib/13_1_power_hungry .pdf. Acesso em: 11set. 2018.
} 
Existem inúmeros casos judiciais tramitando contra a Monsanto nos EUA e em todo mundo com pedidos de indenizaçóes decorrentes dos efeitos maléficos e mortais da utilização dos seus produtos, principalmente do Roundup. ${ }^{36}$

\section{PL DO VENENO (LEI No 6.299/02)}

$\mathrm{O}$ art. 225, $\$ 1^{\circ}, \mathrm{V}, \mathrm{da} \mathrm{CF} / 88$, estabelece que incumbe ao Poder Público "controlar a produção, a comercialização e o emprego de técnicas, métodos e substâncias que comportem risco para a vida, a qualidade de vida e o meio ambiente", este controle é exercido legislativamente, de forma concorrente pela Uniáo, Estados e Distrito Federal, estes de forma suplementar, (CF/88 e Lei no 7.802/89) e quanto ao uso e armazenamento de forma supletiva pelos Municípios. É uma competência vertical, a União estabelece normas gerais, cabendo aos Estados e o Distrito Federal detalhá-las de acordo com especificidade de cada região, não podendo suplantá-las ou confrontá-las. Desta forma, cabe aos Ministérios da Agricultura, Pecuária e Abastecimento, Saúde e do Meio Ambiente, no âmbito de suas respectivas áreas de competências (Decreto no 4.074/2002) a concessão do registro e avaliaçáo de toxicologia humana e ambiental, cujas análises são pautadas em padróes determinados pela FAO. ${ }^{37}$

Esporadicamente a bancada ruralista do Congresso Nacional brasileiro, apresenta um Projeto de Lei visando flexibilizar normas de controle de uso de agrotóxicos no país ou aplicar incentivos fiscais sobre estes produtos. ${ }^{38}$ A Frente Parlamentar de Agropecuária

$36 \quad$ O caso Dewayne Johnson (São Francisco, EUA, 1918), é um destes processos. Johnson em fase terminal de câncer ganhou indenização de 290 milhóes de dólares. A Monsanto foi acusada de omitir informaçóes de risco do produto e agir com omissão quando acionados. LEVIN, Sam. Monsanto ordered to pay \$289m as jury rules weedkiller cause of man's cancer - Court finds in favor of DeWayne Johnson, ill man who was first to take Roundup maker to trial over allegations. The Guardian. Disponível em: https:// www.theguardian.com/business/2018/aug/10/monsanto-trial-cancer-dewayne-johnson-ruling Acesso em $11 / 9 / 18$.

Recentemente a Shell e Basf fecharam indenização milionária com os ex-trabalhadores da fábrica de agrotóxicos controlada pelas empresas que funcionou de 1974 a 2002 no município de Paulínia, no interior de São Paulo. A Shell contaminou o solo e o lençol freático com agrotóxicos contaminando mais de 6 mil pessoas. Muitos desenvolveram câncer. Disponível em: http://reporterbrasil.org.br/2013/04/shell-e-basf-terao-que-pagarindenizacao-milionaria-por-contaminacao-em-fabrica-de-agrotoxicos/2013.Acesso em: 11/9/18.

Em 2017 o TST rejeitou agravo da Rhodia Brasil Ltda. (Concessionária da multinacional francesa RhônePoulenc), contra decisão que a condenou a pagar $\mathrm{R} \$ 100$ mil de indenização por dano moral a um empregado contaminado por hexaclorobenzeno, substância cancerígena. A decisão concluiu que a conduta omissiva da empresa ficou amplamente demonstrada, pois desde 1976 ela despejava na baixada Santista toneladas de resíduos. Disponível em: http://www.tst.jus.br/noticia-destaque/-/asset_publisher/NGo1/content/ id/24221928, 2018.Acesso em: 11/9/18.

\section{$37 \quad$ Op. cit. COSTA, Geovana Specht Vital.}

Existem inúmeros acordos internacionais de regulamentação, redução e eliminação de agrotóxicos: Convenção de Estocolmo sobre Poluentes Orgânicos Persistentes- POP, Protocolo de Montreal Convenção de Roterdam, Convenção de Basileia, convenções da Organização Internacional do Trabalho (OIT) sobre o uso de produtos químicos e segurança e saúde na agricultura, dentre outros.

38 A Bancada ruralista tenta também insistentemente impedir as açóes de combate ao trabalho escravo no Brasil. Como exemplo, citamos a Proposta de Emenda Constitucional (PEC 57A/1999) do trabalho escravo. Op. cit. TALGA, Dagmar Olmo. 
(FPA), bancada que atua na defesa de interesses econômicos do agronegócio brasileiro, composta em sua maioria por latifundiários que financiam as campanhas eleitorais de seus políticos, sempre mostrou resistências ao normativo de proteção ambiental.

Em 2002, a bancada ruralista propôs, através do atual Ministro da Agricultura Blairo Maggi (um dos maiores produtores rurais de soja do Mato Grosso, na época era senador), o Projeto de Lei no 6.299/2002, origem no PLS 526/1999, que altera os arts $3^{\circ}$ e $9^{\circ} \mathrm{da}$ Lei no $7.802 / 89$, que ficou conhecida como "PL do veneno". Durante sua tramitação, o Projeto de Lei 6.299/02 absorveu outros projetos apresentados no Congresso e teve sua redação final apresentada pelo deputado relator Luiz Nashimori (PR-PR) ${ }^{39}$.

O PL do Veneno determina dentre outros, a flexibilização das regras para a fiscalização e para a aplicação dos "agrotóxicos", facilitando o processo de registro e comercialização para favorecimento do agronegócio. Segundo os ruralistas, as medidas propostas de alteração conferem eficiência ao setor da agricultura, porque uma nova substancia que queira adentrar no mercado demora de 4 a 8 anos para ser liberada, já que necessita de ser avaliada pelo Ministério da Agricultura, pelo Ibama, órgáo vinculado ao Ministério do Meio Ambiente, e pela Anvisa, órgáo vinculada ao Ministério da Saúde. Segundo eles, muitas destas substancias já se tornam obsoletas quando são aprovadas.

Pelo Projeto, a Ministério da Agricultura, composto basicamente pelos agropecuaristas, teriam mais poderes no processo de autorização que os demais Ministérios envolvidos na análise e caso esta análise demore mais que 2 anos, o produto iria adentrar no mercado de forma provisória, mesmo sem todo o trâmite analítico de periculosidade concluída. Vai valer ainda um registro temporário dado em 30 dias, caso os produtos já tenham sido autorizados em países membros do Organização para a Cooperação e Desenvolvimento Econômico (OCDE) (como dito acima, tradicionalmente utilizadores de agrotóxicos), ainda que seus efeitos ambientais sejam desconhecidos.

Atualmente se um produto se revela nocivo, com características teratogênicas, carcinogênicas ou metagênicas, causem dano ao meio ambiente e/ou não possuam antídoto, ele não poderá ser aprovado. O PL do Veneno vai omitir estas expressôes legais hoje existentes. Uma das partes mais polêmicas refere-se a nomenclatura dos agrotóxicos que passarão a ser denominados de pesticidas (antes da polêmica cogitou-se até a nomenclatura de fitossanitários), com a desculpa de padronização junto ao Mercosul, no entanto, o real objetivo é ocultar ainda mais da população a periculosidade de consumo e manuseio destes produtos.

Luiz Nashimori chegou a lançar uma campanha em seu site intitulada "Lei do Alimento mais Seguro", onde rebate informaçóes e pesquisas que denunciam a nocividade dos agrotóxicos. O agronegócio intensificou campanhas midiáticas televisivas para angariar

\footnotetext{
$39 \quad$ Projeto de Leis absorvidos no Pacote do Veneno: PL 2495/2000 (6) , PL 3125/2000 (4), PL 5884/2005, PL 6189/2005 (1) , PL 4933/2016, PL 3649/2015, PL 5852/2001 ; PL 1567/2011 (1), PL 4166/2012 ; PL 1779/2011 ; PL 3063/2011 ; PL 1687/2015 (4), PL 3200/2015, PL 49/2015 (2), PL 371/2015 , PL 461/2015 ;PL 461/2015; PL 958/2015; PL 7710/2017 ; PL 8026/2017 ; PL 6042/2016 ; PL 713/1999 (5), PL 1388/1999, PL 7564/2006, PL 4412/2012 (1), PL 2129/2015, PL 5218/2016 ; PL 5131/2016 (1), PL 10552/2018; PL 8892/2017; PL 9271/2017.
} 
simpatizantes do agronegócio brasileiro com o slogan "o agro é pop”. ${ }^{40}$

O Ministério Público da União considera inconstitucional o Projeto do Veneno, em face do artigo 225 e outros da Carta Magna, pelo prejuízo ambiental e à saúde humana causada pela flexibilização e mudanças trazidas no pacote legislativo. Dentre as entidades opositoras e ativistas ambientais, encontram-se a Defensoria Pública, o Ibama, a Anvisa e o Instituto Nacional do Câncer (Inca), Arasco, Fundação Oswaldo Cruz, autoridades e artistas conhecidos.

A OAB durante sua IV Conferência Internacional de Direito Ambiental (Vitória, 2018), elaborou documento pugnando pela rejeição do PL 6.299/02 e de seus substitutivos. Para OAB o PL, nestes 30 anos de Constituição Ambiental, seria o maior retrocesso em matéria ambiental brasileiro.

A Defensoria Pública da União, instituição expoente no acesso à justiça e garantia constitucional da preservação dos Direitos Fundamentais, deixou de ter um cunho exclusivo no assistencialismo jurídico individual, para atender a coletividade como um todo, dentre os quais os direitos ambientais (LC 132/09). Além de tutelas individuais, há uma política de litigância judicial de impacto por meio de Tutelas Coletivas. As Defensorias atuam na orientação e realização de projetos e acordos educativos diante das infrações ambientais, expedição de Notas Técnicas, atuação consultiva e participação em grupos, fóruns e processos legislativos de proteção ao meio ambiente e populaçóes vulneráveis.

No âmbito da Defensoria Pública da União foi criado o Grupo de Trabalho Garantia à Segurança Alimentar e Nutricional (GSAN), instituído pela Portaria DPGF n. 291/2014, SEI 08038.008958/2014-37), com a ocupação de traçar estratégias de atuação relacionadas ao tema, abrangendo açóes que visem a proteção do meio ambiente, garantia de alimentos seguros e saudáveis, tutela e uso racional da água, busca de um modelo de produção, consumo alimentar inteligente, sustentável e sem desperdício e combate ao uso inadequado de agrotóxico.

O combate ao PL 6.299/02 tornou-se um dos eixos principais de atuação no trabalho do GSAN. Segundo a Coordenadora Thais Aurélia, as proposições do PL são uma "tentativa de fragilizar situações de extrema relevância, albergadas por direitos fundamentais e que já estão asseguradas pela legislação infraconstitucional, constitucional e no âmbito do direito internacional".

O PL do veneno apresenta "um grave retrocesso nas políticas públicas brasileiras de proteção da saúde e do meio ambiente, no que se refere ao uso de agrotóxicos, uma verdadeira farra do veneno". ${ }^{41}$ É certo que os agrotóxicos causam danos graves imediatos e mediatos à saúde e ao meio ambiente e ainda é difícil excluir o uso por completo de toda substancia que controla pragas na agricultura, no entanto, flexibilizar as medidas legais protetivas existentes na atualidade é retroceder e desconsiderar as inúmeras informaçóes

40 MOLINA, D. A Farra do Veneno. Disponível em: https://www.brasil247.com/pt/ colunistas/ danilomolina/359767/A-farra-do-veneno.htm, 2018. Acesso em: 11 set. 2018.

41

Ibid. 
hoje existentes quanto aos danos causados pelos agrotóxicos. Informaçóes estas inexistentes em décadas passadas, quando foram utilizados libertinamente porque não foram estudados e ainda não existiam pesquisas a respeito. Mesmo diante da existência de proibitivos legais, ainda há um mercado irregular e informal que atua clandestinamente utilizando e comercializando substancias proibidas.

As medidas legais protetivas básicas estão sendo totalmente desconsideradas no PL do Veneno, como se os próprios parlamentares e agropecuaristas que as desconsideram também não ficassem vulneráveis diante da nocividade dos produtos tóxicos aplicados nas suas lavouras. A busca pelo lucro rápido dá aos mesmos uma falsa ideia da tutela da própria saúde e de suas famílias. $\mathrm{O}$ tempo mostrará que todo homem está inserido no mesmo meio ambiente, sem fronteiras de qualquer espécie. Caso o PL do Veneno seja aprovado, ficaremos todos vulneráveis.

\subsection{Produçáo orgânica e incentivo fiscal}

Uma das grandes estratégias para promover o desenvolvimento rural sustentável é indiscutivelmente o aumento da produção de produtos orgânicos. O consumo orgânico é saudável e compatível com o equilíbrio ambiental. A agricultura orgânica embora pareça inicialmente mais trabalhosa e cara ao agricultor (precisa de mais pessoas para trabalhar a terra em substituição de tanto maquinário), a médio e curto prazo traz benefícios imensuráveis; gera empregos, protege o meio ambiente (animais não humanos, solo e água), o trabalhador e sua família e o consumidor do produto. Gera uma enorme economia para os cofres públicos e para o bolso da população no que se refere aos gastos com saúde.

Enquanto na monocultura há cada vez menos geração de empregos, já que não há necessidade mais de muitos trabalhadores que foram substituídos pelo maquinário agrícola (no plantio, na colheita e na pulverização), a produção de orgânicos movimenta a economia no interior do país. O desemprego no meio rural é um encargo caro para Uniáo que, não raro, paga Benefícios Sociais (LOAS) para matar a fome do povo.

O valor dos produtos orgânicos ainda é muito caro, porque não há incentivos fiscais para a produção, e ainda impera a burocracia e maior fiscalização em pequenas feiras, devido a recentes denúncias de produtos com agrotóxicos sendo vendidos como se fossem orgânicos. Então até mesmo estas feiras, onde os produtos orgânicos poderiam se tornar mais baratos, conhecidos e desejáveis pela população, já há dificuldades de comércio.

A legislação brasileira apoia a indústria do veneno ao conceder inúmeros incentivos fiscais para os produtos químicos em detrimento dos produtos orgânicos. Há uma redução média de 60\% no ICMS, isenção de PIS/COFINS E IPI nos agrotóxicos que são vendidos no Brasil. Corre no STF a ação Direta de Inconstitucionalidade (ADI) 5.553, proposta pelo Partido Socialismo e Liberdade - PSOL, tendo por fundamento a proteção da saúde e os impactos que o uso intensivo e subsidiado dos agrotóxicos causa à saúde pública. A Associação Brasileira de Saúde Coletiva (ABRASCO) ingressou como amicus curiae e em outubro de 2017 a Procuradoria-Geral da República tinha emitido parecer pela inconstitucionalidade na cessão de benefícios fiscais dos Convênio ICMS 100/97 
CONFAZ, e do Decreto Federal 8.950/16 A fundamentação de seu parecer deu-se nos princípios constitucionais do Direito ao Meio Ambiente Ecologicamente Equilibrado (art. 225 da CF), do Direito à Saúde (art. 196) e da Seletividade Fiscal (arts. 153, \$3º., I e $155, \$ 2^{\circ}$., III, da CF). Os tributos possuem uma função social que pode ou não gerar a taxa de extra fiscalidade, para desestimular o consumo, como é feito com cigarro e bebida alcoólica. Não é lógico ao invés de gerar uma taxa maior para os agrotóxicos, eles serem isentos de tributação. ${ }^{42}$

Reduzir a fome e a desigualdade social é desejo de todos porque impacta diretamente na redução do ciclo fome-insegurança pública, campanha de muitos políticos. Ademais está nascendo uma nossa geração de consumidores ambientais conscientes que procuram produtos que não impactam no meio ambiente e são eticamente sustentáveis como orgânicos e veganos ou que de alguma forma realizam um trabalho social. A economia tem que se reinventar para não perder estes consumidores.

Os únicos que não lucram com produção orgânica são as grandes empresas químicas que fabricam sementes geneticamente modificadas, agrotóxicos e medicamentos. No entanto, até estas poderão se reinventar no capitalismo, desenvolvendo tecnologias não nocivas ao meio ambiente e auxiliares na produção orgânica. Para quem transformou explosivos em fertilizantes nada é impossível. Que seja lançado o desafio!

\section{PNARA (PL No 6.670/16)}

Em agosto de 2012, foi instituído a Política Nacional de Agroecologia e Produção Orgânica (Pnapo) para articular políticas públicas que induzam a redução de agrotóxicos e promoção da agroecologia (Decreto Presidencial no 7.794/12). Dentre os instrumentos desta política encontra-se o Plano Nacional de Agroecologia e Produção Orgânica (Planapo), as medidas fiscais, o crédito rural, a formação profissional e tecnológica.

No processo de gestão deste Plano foram instituídas duas instâncias de gestão: A Câmara Interministerial de Agroecologia e Produção Orgânica (Ciapo), composto de diferentes órgãos e entidades do Poder Executivo Federal e a Comissão Nacional de Agroecologia e Produção Orgânica (Cnapo), órgâo de composição paritária entre governo e sociedade civil organizada, democratizando o âmbito de gestáo destas políticas públicas. Neste contexto nasceu o Programa Nacional de Redução de Agrotóxicos (Pronara), estruturado em torno de seis eixos temáticos: 1) Registro; 2) Controle, Monitoramento e Responsabilização de Toda a Cadeia Produtiva; 3) Medidas Econômicas e Financeiras; 4) Desenvolvimento de Alternativas; 5) Informação, Participação e Controle Social; e 6) Formação e Capacitação.

42 Disponível em: https://www.abrasco.org.br/site/outras-noticias/institucional/contra-isencao-fiscal-de-agrotoxicos-abrasco-ingressa-como-amicus-curiae/31040/ 2018. Acesso em: 11/9/18. 
Em 10/11/2016, a Abrasco sugeriu a Comissão de Legislação Participativa da Câmara dos Deputados, o Projeto no 83/2016, transformado no PL no 6.670/2016, que institui a Política Nacional de Redução de Agrotóxicos (Pnara), conhecido como "PL de Redução de Agrotóxico”. Este PL busca alternativas para atual modelo de agro produção brasileira, apoiando a agrologia e a produção orgânica e principalmente a redução do uso de agrotóxico. O deputado Chico Lopes (PCdoB-CE), que já presidiu a comissão, incluiu importantes documentos do Instituto Nacional do Câncer (Inca), alertando para a nocividade destes produtos na saúde humana.

O PL prevê ações integradas de alguns órgãos federais, na fiscalização da importação, produção e comércio dos agrotóxicos, obrigando-os a desenvolverem indicadores de resultados e impactos ambientais. Também prevê qualificaçóes quanto ao uso e manuseio, incentivos econômicos e financeiros para a produção orgânica e agroecológica e o fim dos subsídios para os agrotóxicos. Em junho de 2018, o deputado Alessandro Molon (PSB/RJ), requereu a realização de Audiência Pública para conscientização, participação e debate da sociedade para aprovação do Pnara.

\section{CONCLUSÃO}

A luta no combate ao PL do Veneno não é paritária. Enfrenta-se o poder econômico das indústrias químicas e do agronegócio; a ganância do sistema capitalista pelo lucro fácil; o sistema latifundiário monoculturista arcaico dos países em desenvolvimento; a desinformação da população; o desinteresse da mídia e da população informada; a propaganda falaciosa que "o agronegócio é pop"; a falta de investimento e incentivo em produtos agrícolas orgânicos; o consumo exagerado de alimentação adequada; a miserabilidade e vulnerabilidade dos pequenos agricultores; a crise financeira e a fome.

É preciso Eco alfabetizar. Há uma "falta de educação ambiental” do povo brasileiro que ofende o nosso Texto Constitucional. $\mathrm{O}$ meio ambiente pede socorro. $\mathrm{O}$ uso indiscriminado de agrotóxico no modelo ultrapassado de agronegócio exige informação, participação e legislação de apoio, por isso é tão importante o Pnara.

\section{REFERÊNCIAS}

ACTIONAID INTERNACIONAL.Power hungry six reasons to regulate global food corporations. 2005. Disponível em: https://www.actionaid.org.uk/sites/default/files/ doc_lib/13_1_power_hungry .pdf. Acesso em: 11/9/18.

ANDRIOLI, A. I. FUCHS, Richard. Transgênicos: As sementes do mal - a silenciosa contaminaçáo de solos e alimentos. São Paulo: Expressão Popular, 2008.

ANTUNES, P. de B. Direito Ambiental. Rio de Janeiro, Lumen Juris, 2005. 
BARRIOS, L. Y. Publicación de la Oficina de Estudios y Políticas Agrarias (Odepa) del Ministerio de Agricultura. Gobierno de Chile, 2018.

BOCHNER, R. Sistema Nacional de Informaçóes Tóxico-Farmacológicas - SINITOX e as intoxicaçóes humanas por agrotóxicos no Brasil. Ciência e Saúde Coletiva. Rio de Janeiro, 12 (1): 73- 89, 2007.

BOMBARDI, L. M. Atlas “Geografia do uso de agrotóxicos no Brasil e conexóes com a Uniáo Europeia”. FFLCH USP. São Paulo, 2007. Disponível em: www.larissabombardi. blog.br/atlas. Acesso em: 9 set. 2018.

BURITY, V. Direito humano à alimentaçáo adequada no contexto da segurança alimentar e nutricional. Brasília, DF: ABRANDH, 2010.

BRASIL. Conselho Nacional de Segurança Alimentar e Nutricional. A construção da Política Nacional de Segurança Alimentar e Nutricional. Brasília: CONSEA, 2.007. Disponível em: <https:/www . planalto. gov.br/consea/ static/ documentos /Outros / I I Conferencia.pdf >. Acesso em: 19 de set. 2.007 .

CAMPOS, S. Exposição a agrotóxicos potencializa depressão e suicídio em agrotóxicos. Disponível em: http://www.drashirleydecampos.com.br/noticias/15586,2011. Acessado em: $9 / 9 / 18$.

CARNEIRO, F. F. Dossiê ABRASCO: um alerta sobre os impactos dos agrotóxicos na saúde. In: CARNEIRO, Fernando Ferreira (org). Rio de Janeiro: EPSJV; São Paulo: Expressão Popular, 2015. Disponível em: content/uploads/2013/10/ DossieAbrasco_2015_web.pdf>. Acesso em: 9 set. 2018.

CARSON, R. Primavera Silenciosa. 1.ed. São Paulo: Gaia, 2010.

CHAIM, C. Quem tem fome tem pressa. Isto É. 2002. Disponível em: https://istoe. com.br/27047_QUEM+TEM+FOME+TEM+PRESSA/ Acesso em: 9 set. 2018.

CHEGADEAGROTÓXICO. Querem liberar ainda mais o uso de agrotóxicos no Brasil! Se aprovado, o "Pacote do Veneno" vai colocar mais veneno em nosso prato! Disponível em: https://www.chegadeagrotoxicos.org.br/. Acesso em: 9 set. 2018.

CONSEA. A Segurança Alimentar e Nutricional e o Direito Humano à Alimentaçáo Adequada no Brasil. Indicadores e monitoramento, da Constituiçáo de 1998 aos dias atuais. 2010. Disponível em: http://www4.planalto.gov.br/consea/publicacoes/ publiucacoes-arquivos/a-seguranca-alimentar-enutricional-e-o-direito-humano-aalimentacao-adequada-no-brasil. Acesso em: 10 set. 2018.

COSTA, G. S. V da. Da regulamentação dos agrotóxicos. In: Âmbito Jurídico, Rio Grande, XV, n. 103, ago 2012. Disponível em: <http://ambito-juridico.com.br/site/ index. $\quad \mathrm{php} /$ ?n_link=revista_artigos_leitura\&artigo_id=11864\&revista_caderno=5>. Acesso em: 9 set. 2018.

Convenção de Estocolmo sobre poluentes orgânicos persistentes POPs. 2001. 
Disponível em: http://chm.pops.int/default.aspx . Acesso em: 10 set. 2018.

DERANI, C. Meio Ambiente ecologicamente equilibrado: Direito Fundamental e Princípio da Atividade Econômica, in FIGUEIREDO, Guilherme José Purvin de. (Org.). Temas de Direito Ambiental e Urbanístico. São Paulo: Max Limonad, 1998.

EHLERS, E. Agricultura Sustentável: Origens e perspectivas de um novo paradigma. 2o Ed. Guaíba: Agropecuária, 1999.

FAO. Conferencia Internacional sobre la Gestión de Productos Químicos del Enfoque estratégico para la gestión de productos químicos a nivel internacional. Disponível em: http://www.fao.org/news/story/ es/item/414021/icode/ 2016. Acesso em: 11 set. 2018 .

FAO. State of Food Insecurity in the World. A Food and Agriculture Organization (FAO). Diponível em :http://www.fao.org/3/a-i4037e.pdf. Acesso em: 9 set. 2018.

Lei dos Agrotóxicos - Lei no 7.802, de 11 DE julho de 1989. Disponível em http:// www.planalto.gov.br/ccivil_03/Leis/L7802.htm. Acesso em : 10 set. 2018.

Lei Orgânica de Segurança Alimentar e Nutricional - Lei no 11.346 de 15 de setembro de 2006. Disponível em: http://www.planalto.gov.br/ccivil_03/_ato2004-2006/2006/ lei/ 111346. htm. Acesso em: 10 set. 2018.

LEVIN, S. Monsanto ordered to pay $\$ 289 \mathrm{~m}$ as jury rules weedkiller cause of man's cancer - Court finds in favor of DeWayne Johnson, ill man who was first to take Roundup maker to trial over allegations. The Guardian. Disponível em: https://www. theguardian.com/business/2018/aug/10/monsanto-trial-cancer-dewayne-johnson-ruling Acesso em: 11 set. 2018.

MEDEIROS, M. F. A. A problemática do uso de agrotóxicos no brasil: análise jurídica acerca dos impactos ao meio ambiente e à saúde pública frente aos interesses corporativos. Disponível em: http://www.inverbis.com.br/site2010/wp-content/uploads/2017/07/42aEDIC\%CC\%A7A\%CC\%83O-REVISTA-JURI\%CC\%81DICA-IN-VERBIS-v1.601122017-pag285-306.pdf. Acesso em: 11 set. 2018.

MINSAL Padrão para vigilância de intoxicaçóes agudas por agrotóxicos. REVEP. Santiago, Ministério da Saúde do Chile, 2007.

MOLINA, D. A Farra do Veneno. Disponível em: https:/www.brasil247.com/pt/ colunistas/danilomolina/359767/A-farra-do-veneno.htm, 2018. Acesso em: 9 set. 2018.

Norma técnica de Vigilancia de intoxicaciones Agudas por plaguicidas REVEP División de Planificación Sanitaria Departamento de Epidemiología. Ministério da Saúde do Governo do Chile, 2007.

PALAEZ, V. Mercado e Regulação de Agrotóxicos. Curitiba, CONSEA.2012. Disponível em: http://www.consea.pr.gov.br/arquivos/File/ ANEXO4AGROTOXICOSCONSEAPR.pdf. Acesso em : 9/9/18. 
PIGNATI, W. Agronegócio, agrotóxicos e saúde. In: OLIVEIRA DE SOUZA, Murilo Mendonça (Org). Agrotóxicos - violaçóes socioambientais e direitos humanos no Brasil Anápolis: Editora Universidade Estadual de Goiás, 2016, pags 17 a 45.

PIGNATI, W. Os efeitos dos agrotóxicos na saúde humana. UFMT Seminário internacional contra os agrotóxicos e pela vida Fórum estadual de combate aos agrotóxicos do Paraná 2012.Disponível em: http://www.meioambiente.mppr.mp.br/arquivos/File/ EFEITO_DOS_AGROTOXICOS_PIGNATI . pdf. Acesso em: 8/6/2006.

QUEZADA, M. T. M. Aspectos bioéticos no controle e aplicaçáo de agrotóxicos no Chile. 2011.Disponível em :http://dx.doi.org/10.4067/S1726-569X2011000100011 . Acesso em: 9 set. 2018.

REIS, S. N. N. Uma visáo holística do direito: manual prático para o jurista do $3^{\circ}$ milênio. Belo Horizonte: Nova Alvorada, 1997. p. 256.

ROBIN, M.-M. O Mundo segundo a Monsanto - da dioxina aos transgênicos, uma multinacional que quer o seu bem. São Paulo: Radical Livros, 2008.

ROTHLEIN J, ROHLMAN D, LASAREV M, PHILLIPS J., MUNIZ J, MCCAULEY L. Exposiçáo de pesticidas organofosforados e desempenho neurocomportamental em trabalhadores hispânicos agrícolas e náo-agrícolas. Environ Health Perspect 2006, 114 (5): 691-696.

ROSSI, M. El país. São Paulo, 2015. Disponível em: https://brasil.elpais.com/brasil/ 2015/04/29/politica/ 1430321822_851653.html?rel=mas. Acesso em: 9 set. 2018.

SAG. Ano de declaração de vendas de pesticidas de 2006. Serviço de Pecuária Agrícola Santiago do Chile, 2008.

SARLET, I. W. A eficácia dos direitos fundamentais. 6 ed. rev. atual. e ampl. Porto Alegre, Livraria do Advogado. 2006.

TALGA, D. Pontal do Buriti. Brincando na chuva de veneno. Diretora Dagmar Talga, 2013. Disponível em: https:/www.youtube.com/watch?v=qHQdWwZcGlg. Acesso em: 9 set. 2018.

TALGA, D. O. e TALGA, J. V. B. O poder do agronegócio e a mídia: Analise a partir da pulverização aérea de agrotóxico sobre a escola municipal São Jose do pontal, In OLIVEIRA DE SOUZA, Murilo Mendonça (org.) Agrotóxicos - violaçóes socioambientais e direitos humanos no Brasil. Anapolis: Editora Universidade Estadual de Goiás, 2016, pag 137-170.

TOLEDO, T. A doença é um ótimo negócio no capitalismo. Disponível em: https:// caviaresquerda.blogspot.com/2018/07/a-doenca-e-um-otimo-negocio-no.html.Acesso em $9 / 9 / 18$.

VAZ, P. A. B. O Direito Ambiental e os agrotóxicos: responsabilidade civil, penal e administrativa. Porto Alegre: Livraria do Advogados, 2006. 
VILLAS BOAS, B. Pobreza extrema aumenta $11 \%$ e atinge 14,8 milhóes de pessoas. Valor Econômico, 2018. Diponível em:https://www.valor.com.br/brasil/5446455/ pobreza-extrema-aumenta-11-e-atinge-148-milhoes-de-pessoas. Acesso em 9/9/18.

WAICHMAN, A. V. A problemática do uso de agrotóxicos no Brasil: a necessidade de construção de uma visão compartilhada por todos os atores sociais, 2012. Disponível em:http://www.inverbis.com.br/site2010/wp-content/uploads/2017/07/42a-EDIC\% CC\%A7A\%CC\%83O-REVISTA-JURI\%CC\%81DICA-IN-VERBIS-v1.6-01122017pag285-306.pdf. Acesso em: 9 set. 2018.

What the Health. Documentário. Disponível em: <https://www.youtube.com/watch? v= NoYINM gImGs, 2017>. Acesso em: 9 set. 2018. 